УДК 336.763.4

DOI: https://doi.org/10.32782/2415-8801/2020-4.15

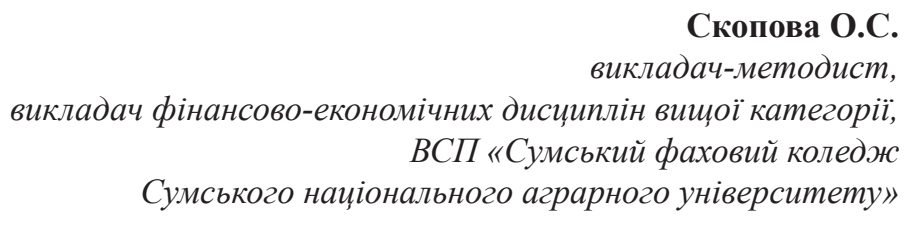

\author{
«ЗЕЛЕНІ» ОБЛІГАЦІЇ ЯК ІНСТРУМЕНТ ЗАБЕЗПЕЧЕННЯ \\ ВІДТВОРЕННЯ ПРИРОДНИХ РЕСУРСІВ В АГРАРНІЙ СФЕРІ: \\ СВІТОВИЙ ДОСВІД ТА МОЖЛИВОСТІ ЗАСТОСУВАННЯ В УКРАЇНІ
}

Підприємства аграрної сфери мають свої специфічні характеристики, одна з яких полягас у використанні у виробничому процесі земельних ресурсів та жсиих організмів. Ці природні ресурси с вичерпними та потребують постійного відновлення. Існуючі в нашій крайні фінансові інструменти не с дієвими, тому необхідо вивчати та використовувати новітні інструменти, наприклад «зелені» цінні папери. У статті розглянуто світовий досвід використання «зелених» цінних паперів для реалізації екологічних проєктів. Проаналізовано загальний випуск «зелених» бондів за період 2015-2019 рр. Сьогодні вже приблизно 40 держав свіму залучені до обігу «зелених» бондів. Досліджено структуру випуску за емітентами-краӥнами та сферами використання. Лідерами-емітентами виступають США, Китай та Франція. Розглянуто основні зміни в законодавстві Украӥни щцодо формування та впровадження ринку «зелених» облігацій, щцо забезпечить залучення нових інвестицій у сферу енергоефективності, екологічного транспорту, запобігання забрудненню, сталий розвиток аграрної сфери. Наголошено на можллвості та необхідості застосування «зелених» облігацій для забезпечення відтворення природних ресурсів в аграрній сфері.

Ключові слова: інструменти фінансового забезпечення відтворення природних ресурсів в аграрній сфері, иінні папери, «зелені» бонди, «зелені» облігаџії, проєкти екологічного спрямування.

\title{
GREEN BONDS AS A TOOL FOR ENSURING THE REPRODUCTION OF NATURAL RESOURCES IN THE AGRICULTURAL SPHERE: WORLD EXPERIENCE AND POSSIBILITIES OF APPLICATION IN UKRAINE
}

\section{Skopova Elena Sumy National Agrarian University}

Agricultural enterprises have their own specific characteristics, one of which is the use of land resources and living organisms in the production process. These natural resources are exhaustible and need constant renewal. Agricultural enterprises lack their own sources of financing for the reproduction of natural resources. After all, to ensure the production of quality and competitive products, it is necessary to constantly improve equipment and technology. Thus, the issue of reproduction of natural resources often recedes into the background. According to the current regulations in Ukraine, the main sources of funding for the reproduction of natural resources and environmental measures are the general fund of state and local budgets; environmental protection funds (state ecological funds); free funds of economic entities and international assistance. Today in Ukraine the main financial instrument for ensuring the reproduction of 
natural resources is environmental taxation. It is the main tool of state influence and regulation of the reproduction of natural resources. Unfortunately, environmental taxes do not perform their main functions, as their amount is dissolved in the general fund of the State budget. The way out of this situation is to attract new sources of financing, such as green securities. The article considers the world experience of using green securities since 2008 for the implementation of environmental projects. The total issue of green bonds for the period from 2015 to 2019 is analyzed and the prospects of its development are indicated. Today, about 40 countries are involved in the circulation of green bonds. The structure of the issue by issuers-countries and spheres of use is studied. The leaders - issuers of green bonds are the United States, China and France. The article also considers the main changes in the legislation of Ukraine on the formation and implementation of the green bond market from 2020. That will ensure the attraction of new investments in the field of energy efficiency, ecological transport, pollution prevention, sustainable development of the agricultural sector. The definition and classification of environmental projects in accordance with the legislation of Ukraine is given. The author emphasizes the possibilities and necessity of using green bonds to ensure the reproduction of natural resources in Ukraine, which will significantly expand the financial capabilities of agricultural enterprises.

Keywords: financial support instruments for the reproduction of natural resources in the agricultural sector, securities, green bonds, green bonds, environmental projects.

Постановка проблеми. Функціонування підприємств аграрної сфери без залучення природних ресурсів $\epsilon$ неможливим. Використання земельних та інших видів ресурсів як основних засобів виробництва та як складових елементів продуктивних сил зумовлене специфікою їх функціонування. Фінансове забезпечення та інші питання, що виникають у процесі проведення природоохоронних заходів, вирішуються через застосування певних джерел та інструментів для відтворення природних ресурсів.

Як свідчить практика, власних джерел фінансування відтворення природних ресурсів не вистачає підприємствам аграрної сфери, адже для забезпечення виробництва якісної та конкурентоспроможної продукції необхідно постійно вдосконалювати техніку та технологію. Таким чином, питання відтворення природних ресурсів досить часто відходять на другий план. Виходом із такої ситуації є залучення зовнішніх джерел фінансування.

Відповідно до чинних нормативно-правових актів в Україні основними джерелами фінансування відтворення природних ресурсів та природоохоронних заходів є загальний фонд державного та місцевих бюджетів, фонди охорони навколишнього середовища (державні екологічні фонди), вільні кошти суб’єктів господарювання та міжнародна допомога.

Сьогодні в Україні основним фінансовим інструментом забезпечення відтворення природних ресурсів $\epsilon$ екологічне оподаткування. Це основний інструмент державного впливу та регулювання відтворення природних ресурсів. На жаль, екологічні податки не виконують свої основні функції, оскільки їх сума розчиняється у загальному фонді державного бюджету.

Тому, на нашу думку, доцільно звернути увагу на нові інструменти фінансового забезпечення відтворення природних ресурсів, у тому числі «зелені» облігації, які є досить розповсюдженими в усьому світі.

Аналіз останніх досліджень і публікацій. Дослідженню обігу «зелених» цінних паперів присвячено праці таких учених, як Г. Перелигіна-Ковальчук [1], В.М. Дорошенко [7], А. Фролов та ін.

Постановка завдання. Метою статті $є$ узагальнення теоретичних аспектів щодо застосування інноваційного досвіду з використання нового фінансового інструменту - «зелених» облігацій для забезпечення відтворення природних ресурсів в аграрній сфері.

Виклад основного матеріалу дослідження. Із упровадженням Концепції сталого розвитку більше уваги зосередилося на обмеженості ресурсів навколишнього середовища та питанні пошуку нових джерел для їх відтворення. Одним із фінансових інструментів, який допоможе подолати розрив між потребою в збільшенні виробництва в аграрній сфері і турботою про навколишнє середовище, є «зелені» облігації. Уперше вони з'явилися на ринках у 2008 р. Хоча існують різні види «зелених» облігацій, у цілому це облігації, доходи від яких повністю або частково використовуються для проєктів, що реалізують позитивний вплив на навколишнє середовище.

Згідно зі стандартами, встановленими Міжнародною асоціацією ринків капіталу, «зелені» облігації повинні відповідати чотирьом ключовим принципам: цільове використання коштів, процес оцінки и відбору екопроєктів, забезпечення управління коштами та формування звітності про вплив [1].

Міжнародною асоціацією ринків капіталу проєкти в аграрній сфері прямо кваліфікуються як «зелені». Відповідно до вищезазначених принципів, такі проекти включають «екологічно збалансоване управління живими природними ресурсами і землекористуванням (у тому числі екологічно стале сільське господарство, біологічний захист сільськогосподарських культур або крапельне зрошення, екологічно стійке рибальство i аквакультура, екологічно стале лісове господарство, включаючи залісення або відтворення лісів, а також збереження або відновлення природних ландшафтів)» [2].

«Зелені» облігації можуть мати значний вплив на фінансову й аграрну сфери. Відповідно до звіту Nikko Asset Management 2017 р., до 2020 р. вартість емітованих «зелених» облігацій і тих, що знаходяться в обігу, може сягнути 1,2 трлн дол. США [2].

Приблизно 40 держав світу вже є емітентами «зелених» облігацій, серед яких лідерами є США, Китай та Франція, а обсяг світового випуску в 2019 р. сягнув 255 млрд дол. США (рис. 1).

Європа - світовий лідер із випуску «зелених» облігацій. У сукупності країни з розвиненим ринком «зелених» облігацій у 2019 р. випустили їх на загальну суму 106,7 млрд дол. США (рис. 2). США очолюють національний рейтинг із 50,6 млрд дол. США, Китай - 30,1 млрд дол. США, Франція - 29,5 млрд дол. США [3]. Найбільшим емітентом «зелених» облігацій сьогодні виступає Свропейський інвестиційний банк, який допомагає налагоджувати національні ринки «зелених» облігацій у країнах.

Згідно з оцінками Climate Bonds Initiative (CBI), фінансування за рахунок «зелених» облігацій для сталого сільського та лісового господарства вже виросло до 11,3 млрд дол. у 2019 р. $з$ 1,1 млрд дол. у 2015 р. та займає $3 \%$ у загальній структурі (рис. 3) [4]. 


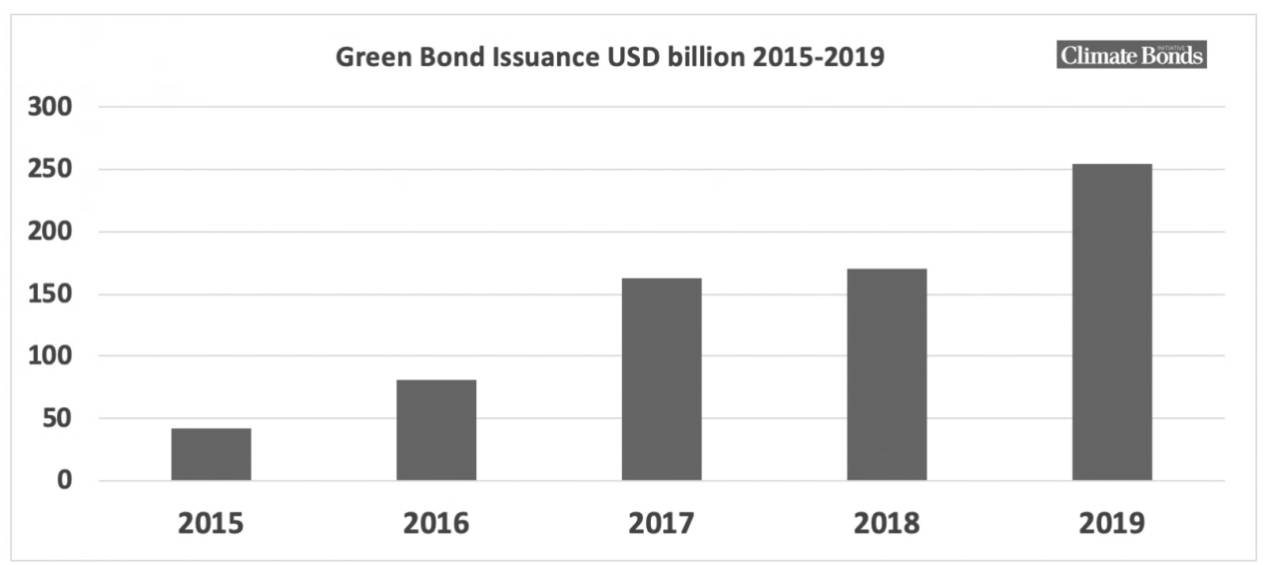

Рис. 1. Загальна щорічна емісія «зелених» бондів за період 2015-2019 рр. Джерело: взято автором із [3]

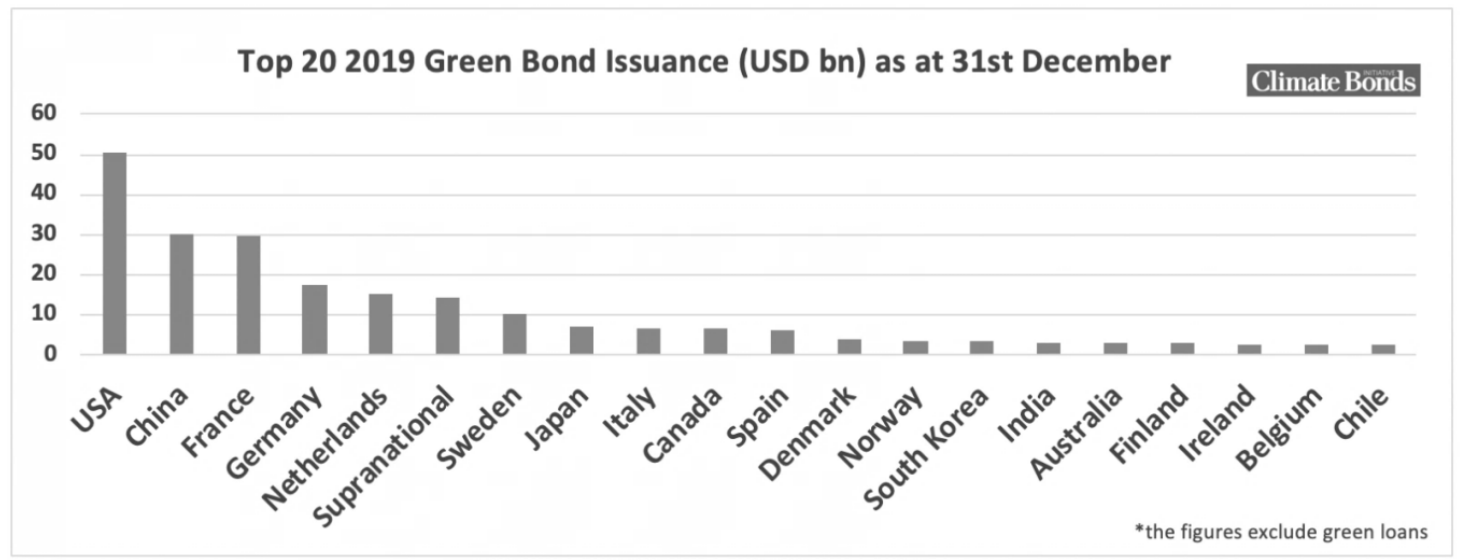

Рис. 2. Топ-20 країн за випуском «зелених» бондів станом на 31 грудня 2019 р. Джерело: взято автором із [3]

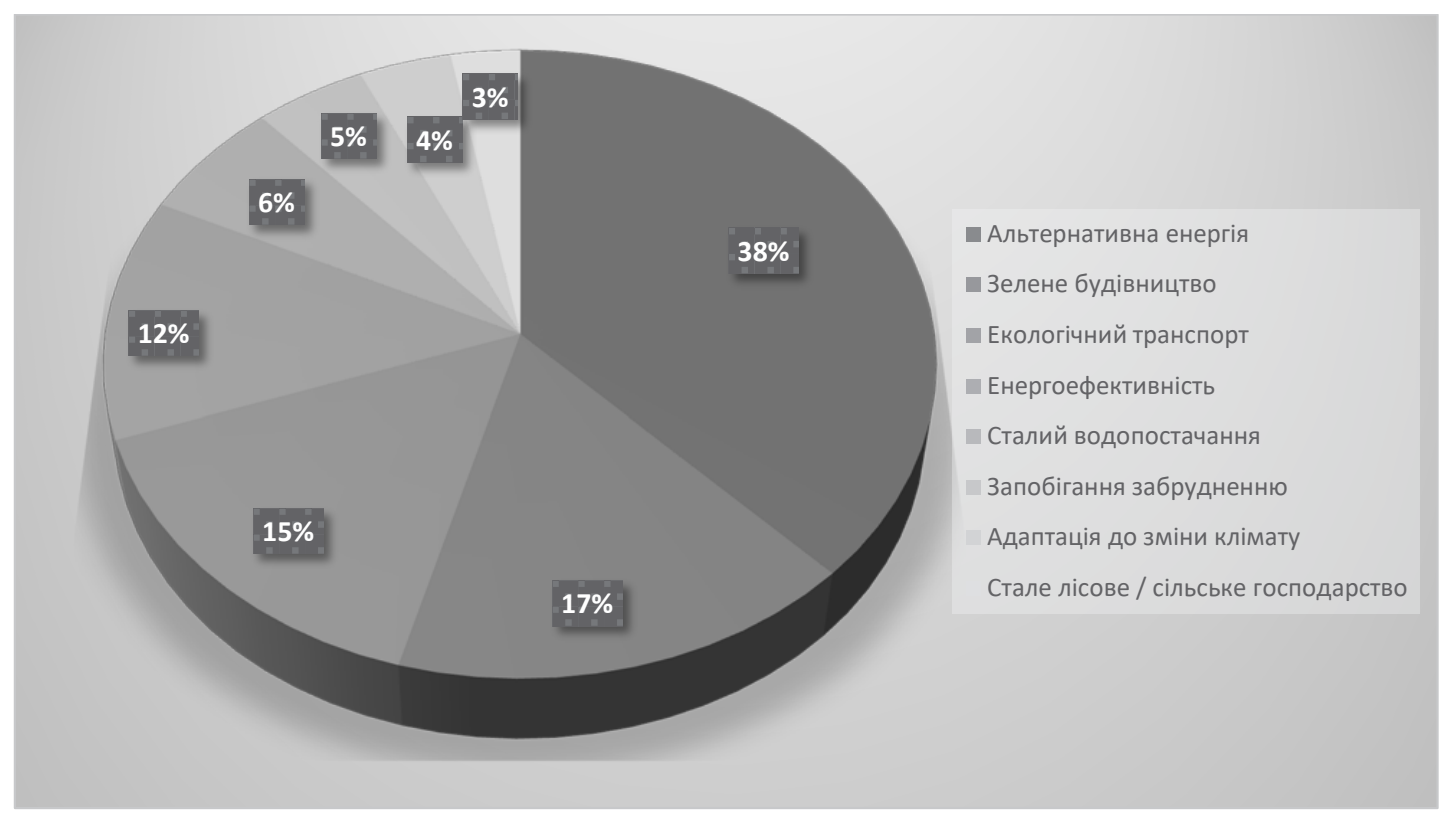

Рис. 3. Структура «зелених» облігацій за сферами обігу в 2019 р. Джерело: складено автором на основі [4] 


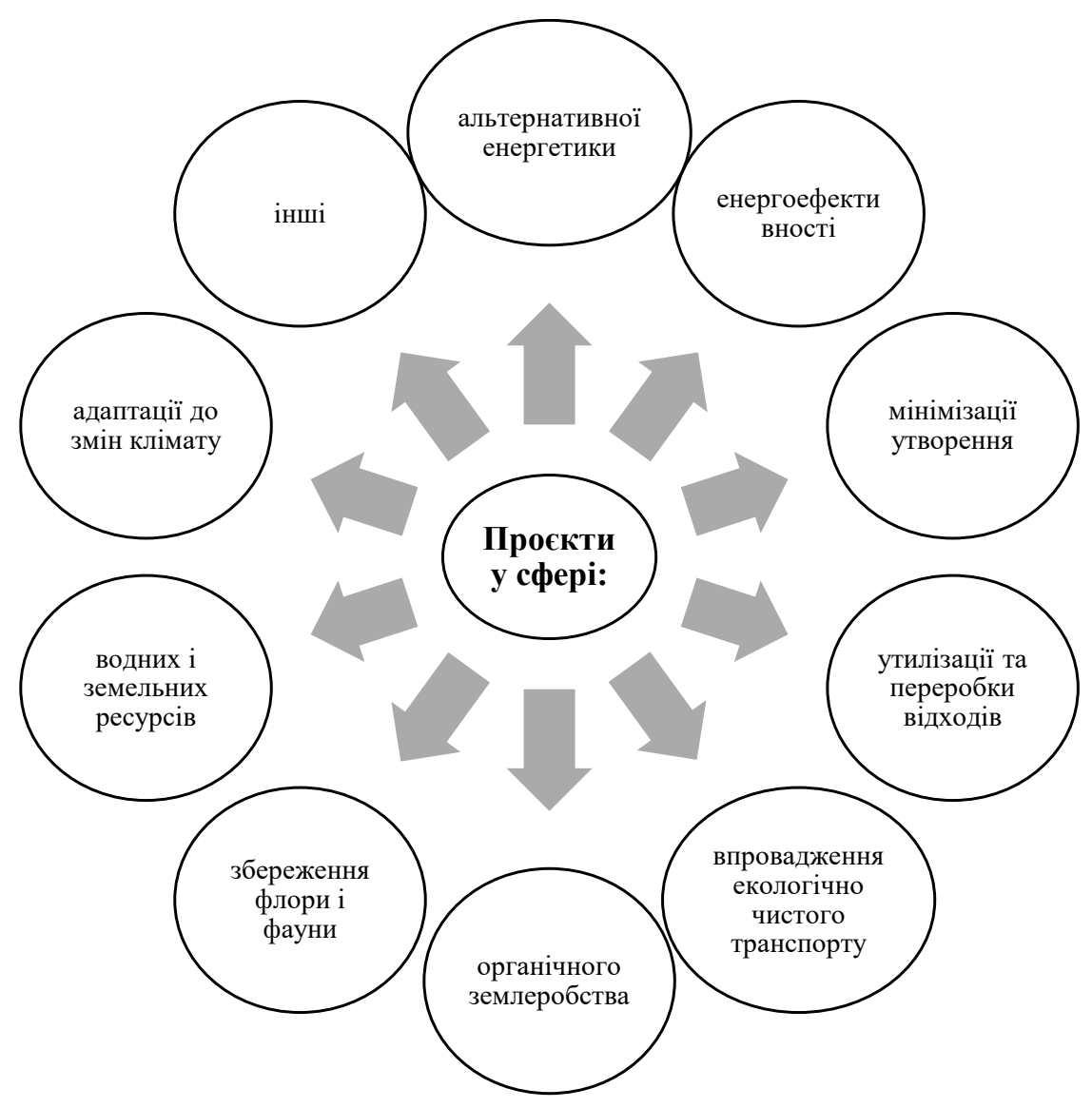

Рис. 4. Види просктів екологічного спрямування

Джерело: складено автором на основі [5]

В Україні ринок «зелених» цінних паперів знаходиться на початку розвитку. Так, із 16 серпня 2020 р. став чинним Закон України № 738-IX [5], нормами якого встановлено правила роботи для учасників ринку «зелених» облігацій. У статті 18 визначено «зелені» облігації як цінні папери, кошти від яких спрямовуються на фінансування (рефінансування) проєктів екологічного спрямування. Види проєктів наведено на рис. 4 [5].

Емітентами «зелених» облігацій в Україні, відповідно до пункту 3.2 статті 18 Закону № 738-IX, може бути держава в особі уповноважених органів, територіальна громада в особі представницького органу місцевого самоврядування або юридична особа.

Державним агентством 3 енергоефективності та енергозбереження 14 серпня 2020 р. було розроблено проєкт Концепції запровадження ринку «зелених» облігацій в Україні, який передбачає на першому етапі (2020-2021 рр.) створити правові передумови для функціонування ринку та введення в обіг стандартних облігацій, а на другому (2021-2022 рр.) - сприяти розвитку ринку через уведення в обіг ще й проєктних, сек'юритизованих та дохідних «зелених» облігацій [6]. Відповідно до проєкту Концепції, плануються зміни до Податкового кодексу України з метою скасування податку з доходів у вигляді відсотків (дисконту), отриманого власником «зеленої» облігації.

Особливість емісії «зелених» облігацій полягає у тому, що до її початку має бути проведена незалежна експертиза вибраного проєкту критеріям «зеленості» та встановлена відповідна прозора процедура контролю та звітності щодо процесу реалізації та отриманих ефектів від проєкту [7].

Висновки 3 проведеного дослідження. Таким чином, задоволення зростаючих світових потреб у продовольстві і забезпечення екологічної безпеки в майбутньому вимагають творчих фінансових рішень. «Зелені» облігації мають великий потенціал, щоб стати важливим фінансовим інструментом у досягненні цілей виробництва продуктів харчування і охорони навколишнього середовища.

Хоча «зелені» облігації часто обертаються на відкритому ринку, вони також можуть розміщуватися у приватному порядку. Це створює дуже цікаву альтернативу для невеликих підприємств аграрної сфери, у яких є сильні проєкти для фінансування, але які можуть не мати права на торгівлю на відкритих ринках або захочуть адаптувати умови випуску облігацій для конкретних інвесторів.

\section{Список використаних джерел:}

1. Перелигіна-Ковальчук Г. (2019) Перспективи розвитку зелених облігацій в Україні. URL: https://esquires.ua/ perspektivi-rozvitku-zelenih-obligatsij-v-ukrayini/\#: :text=Для\%20відповідності\%20«зелених»\%20облігацій\%20 цим,проектів\%2С\%20управління\%20коштами\%20та\%20звітність (дата звернення: 22.10.2020). 
2. Green Bonds and Agriculture Project Finance. URL: https://www.onetoonecf.com/green-bonds-and-agricultureproject-finance/ (дата звернення: 22.10.2020).

3. Record 2019 GB Issuance \$255bn! EU largest market: US, China, France lead Top 20 national rankings: Sovereign GBs \& Certified Bonds gain momentum. URL: https://www.climatebonds.net/2020/01/record-2019-gb-issuance-255bneu-largest-market-us-china-france-lead-top-20-national (дата звернення: 21.10.2020).

4. New Waves: The ESG Megatrend Meets Green Bonds. URL: https://www.visualcapitalist.com/esg-megatrendgreen-bonds/ (дата звернення: 21.10.2020).

5. Про внесення змін до деяких законодавчих актів України щодо спрощення залучення інвестицій та запровадження нових фінансових інструментів : Закон України від 19 червня 2020 р. № 738-IX / Верховна Рада України. URL: https://zakon.rada.gov.ua/laws/show/738-20\#Техt (дата звернення: 21.10.2020).

6. «Зелені» облігації можуть залучити 73 мільярди доларів США інвестицій в Україну. Укрінформ. URL: https:/www.ukrinform.ua/rubric-economy/2716283-zeleni-obligacii-mozut-zaluciti-73-milardi-investicij-v-ukrainu.html (дата звернення: 21.10.2020).

7. Дорошенко В.М. Сучасні інструменти забезпечення фінансування енергозбереження: green finances. Збірник наукових пращь Черкаського державного технологічного університету. Серія «Економічні науки». 2018. Вип. 50. С. 49-54. URL: http://nbuv.gov.ua/UJRN/Znpchdtu_2018_50_8 (дата звернення: 21.10.2020).

\section{References:}

1. Ganna Perelygina-Kovalchuk (2019) Perspektyvy rozvytku zelenyx obligacij v Ukrayini [Prospects for the development of green bonds in Ukraine]. Retrieved from: https://esquires.ua/perspektivi-rozvitku-zelenih-obligatsij-v-ukrayini/\#: :text=Для\%20відповідності\%20«зелених»\%20облігацій\%20цим,проектів\%2C\%20управління\%20 коштами\%20та\%20звітність (accessed 22 October 2020). (in Ukrainian)

2. Green Bonds and Agriculture Project Finance. Retrieved from: https://www.onetoonecf.com/green-bonds-and-agriculture-project-finance/ (accessed 22 October 2020). (in English)

3. Record 2019 GB Issuance \$255bn! EU largest market: US, China, France lead Top 20 national rankings: Sovereign GBs \& Certified Bonds gain momentum. Retrieved from: https://www.climatebonds.net/2020/01/record-2019-gb-issuance-255bn-eu-largest-market-us-china-france-lead-top-20-national (accessed 22 October 2020). (in English)

4. New Waves: The ESG Megatrend Meets Green Bonds. Retrieved from: https://www.visualcapitalist.com/esgmegatrend-green-bonds/ (accessed 22 October 2020). (in English)

5. Pro vnesennya zmin do deyakyx zakonodavchyx aktiv Ukrayiny shhodo sproshhennya zaluchennya investycij ta zaprovadzhennya novyx finansovyx instrumentiv: Zakon Ukrayiny (2020). Retrieved from: https://zakon.rada.gov.ua/ laws/show/738-20\#Text (accessed 22 October 2020). (in Ukrainian)

6. «Zeleni» obligaciyi mozhut zaluchyty 73 milyardy dolariv SShA investycij v Ukrayinu. Ukrinform [Green bonds could attract $\$ 73$ billion in investment in Ukraine] (2020). Retrieved from: https://www.ukrinform.ua/rubric-economy/2716283-zeleni-obligacii-mozut-zaluciti-73-milardi-investicij-v-ukrainu.html (accessed 22 October 2020). (in Ukrainian)

7. Doroshenko V.M. (2018) Suchasni instrumenty zabezpechennya finansuvannya energozberezhennya: «green finances» [Modern tools for energy financing: "green finances"]. Retrieved from: http://nbuv.gov.ua/UJRN/Znpchdtu_ 2018_50_8 (accessed 22 October 2020). (in Ukrainian)

E-mail:Elenaskopova5@gmail.com 